\title{
STRATEGI REVITALISASI PENGELOLAAN PERPUSTAKAAN UNIVERSITAS BENGKULU
}

\author{
Nanik Rahmawati, S.Sos.,M.Hum.
}

nanikr@unib.ac.id

\begin{abstract}
Abstrak:
Strategi revitalisasi pengelolaan perpustakaan merupakan suatu inovasi yang relevan dengan perubahan lingkungan strategis. Proyek Perubahan ini memiliki peranan yang strategis bagi Universitas Bengkulu dalam upaya pengembangan layanan prima untuk merespon tuntutan dan perubahan paradigma birokrasi. Inovasi dalam proyek perubahan ini diharapakn mampu menyelesaikan permasalahan yang ada di layanan administrasi bebas pustaka khususnya di Universitas Bengkulu. Proyek perubahan ini menghasilkan kebijakan strategi pengembangan layanan bebas pustaka yaitu dengan adanya kebijakan sebagai dasar hukum operasional layanan. Strategi pengembangan layanan bebas pustaka melibatkan bagian evaluasi dan pembelajaran, UPT Perpustakaan Unib serta ruang baca 8 fakultas terintegrasi menjadi kesatuan layanan. Sistem layanan bebas pustaka merupakan inovasi yang dirancang oleh Universitas Bengkulu yang dilaksanakan secara kolaboratif di lingkungan universitas melalui sistem informasi yang terintegrasi dengan tujuan baik staf maupun mahasiswa mampu untuk beradaptasi secara dinamis melalui pengembangan layanan secara berkelanjutan sehingga universitas mampu menjadi organisasi yang agile dan adaptif menuju organisasi pembelajar.Sistem pengembangan layanan bebas pustaka merupakan salah satu manajemen perubahan dalam reformasi birokrasi dalam rangka memberikan layanan yang efektif dan efisien agar dapat bersaing menuju SDM unggul. Proyek perubahan ini juga sejalan dengan Visi universitas yaitu menuju World Class Universty.
\end{abstract}

Kata Kunci: Manajemen Pengelolaan Perpustakaan - Layanan online

\begin{abstract}
Abstrack:
The revitalization of library management is a breakthrough innovation that is relevant to changes in the strategic environment. This Change Project has a strategic role for Bengkulu University in an effort to develop excellent services to respond to demands and changes in the bureaucratic paradigm. The innovation in this change project is able to solve the problems that exist in library-free administration services, especially at Bengkulu University. This change project resulted in a library-free service development strategy policy, namely the existence of a policy as the legal basis for service operations. The strategy for developing library-free services involves the evaluation and learning section, the Unib Library UPT and the reading rooms of 8 faculties are integrated into a service unit. The library-free service system is an innovation designed by Bengkulu University which is carried out collaboratively within the university through an integrated information system with the aim that both staff and students are able to adapt dynamically through continuous service development so that the university is able to become an agile and adaptive organization towards an organization. Learners. The library-free service development system is one of the management changes in bureaucratic reform in order to provide effective and efficient services in order to compete towards superior human resources. This change project is also in line with the university's vision, namely towards a world class university.
\end{abstract}

Keywords: Library Management Management - Online service

\section{Latar Belakang}

Pandemi covid-19 mengakibatkan perubahan diberbagai bidang salah satunya perpustakaan. Perpustakaan yang selama ini melakukan layanan secara manual atau tatap muka wajib melakukan pembenahan khususnya dalam hal layanan. Proses pembenahan ini memiliki nilai yang sekaligus menjadi tugas utama lembaga yaitu memberikan layanan prima dengan menyediakan fasilitas pendukung sehingga proses lebih 
cepat serta akurat yang dapat mingkatkan kinerja lembaga (organization agile). Universitas Bengkulu harus dapat menjadi harus dapat menjadi organisasi yang agile dan adaptif yang mengandung makna sebagai organisasi yang tangkas dan responsif terhadap perubahan lingkungan strategis sejalan dengan visi dan misi Universitas Bengkulu yaitu menjadi universitas kelas dunia pada tahun 2025 sedangkan misinya mengembangkan pendidikan dan penelitian berkelas dunia; menghasilkan karta berstatus Hak atas Kekayaan Intelektual (HKI); melaksanakan pengabdian sesuai dengan kebutuhan masyarakt lokal, nasional dan internasional; serta mengembangkan sistem tata kelola universitas yang baik dan bersih.

Strategi revitalisasi pengelolaan layanan perpustakaan adalah upaya untuk pemenuhan kebutuhan layanan administrasi bebas pustaka dengan standar kompetensi layanan. Belum adanya keseragaman layanan, serta sistem layanan yang masih manual mengakibatkan pengulangan layanan. Selain itu belum ada regulasi terkait layanan bebas pustaka selingkung universitas. Sistem layanan yang ada belum terintegrasi dalam proses layanan sehingga seringkali menghambat dalam pelaksanaan kinerja staf.

Gambar 1 Kondisi Saat Ini dan Kondisi yang Diinginkan

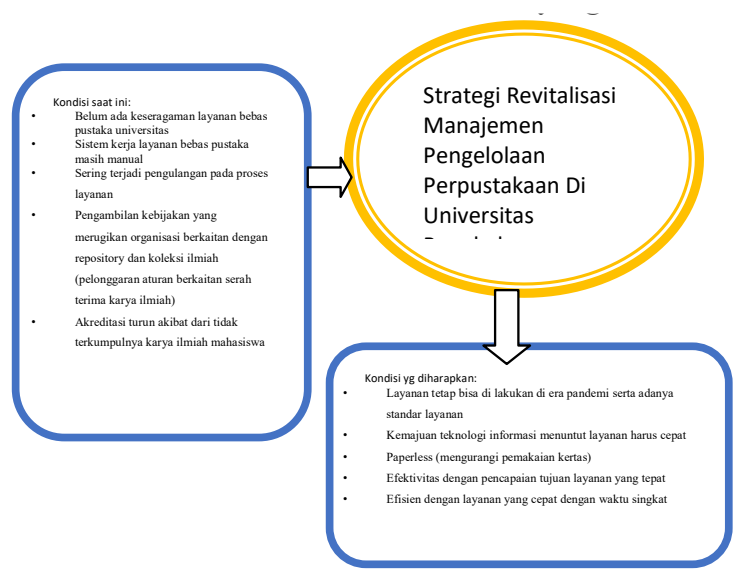

Bhimo widyo Andoko, $2020^{1}$

Penerima manfaat langsung adalah mahasiswa di lingkungan Universitas Bengkulu yang akan wisuda. Manfaat internal antara lain;

- Tersedianya kebijakan sebagai dasar operasional standar layanan bebas pustaka di Universitas Bengkulu.

- Tersedianya sistem dan keseragaman layanan bebas pustaka terintegrasi di Universitas Bengkulu.

- Tersedianya laporan bebas pustaka secara berkala sebagai bahan pengambilan kebijakan atau melakukan monitoring dan evaluasi.

- Tersedianya manajemen pengelola yang mendukung perubahan pola pikir terhadap perubahan layanan dalam organisasi.

- Tersedianya laporan data bebas pustaka yang terintegrasi dalam pengembangan layanan di Universitas Bengkulu.

Penerima manfaat secara tidak langsung adalah stakeholder eksternal selingkung Universitas Bengkulu, yaitu;

- Memudahkan pihak terkait untuk mendapatkan informasi tentang bebas pustaka terintegrasi di Universitas Bengkulu;

- Tersedianya informasi bagi pemangku kepentingan sebagai bahan pengambilan kebijakan dalam pengembangan layanan terintegrasi di Universitas Bengkulu.

Semantara, dari segi Output dan Outcome antara lain;

\section{Output}

- Tersusunnya kebijakan atau peraturan yang menjadi dasar operasional layanan.

- Terbentuknya manajemen pengelola untuk menerapkan pola penyelenggaraan.

- Terciptanya layanan bebas pustaka yang sesuai dengan standar pelayanan minimal yang ditetapkan.

\footnotetext{
${ }^{1}$ Widyo Andoko, Bhimo. 2020. Strategi Peningkatan Kinerja Layanan Lembaga Pendidikan Tinggi Wilayah V Yogyakarta yang Terintegrasi dan Akuntabel.Jakarta: Kerjasama Lembaga Administrasi Negara dan Pusat Pendidikan dan Pelatihan Pegawai Kementrian Pendidikan dan Kebudayaan Republik Indonesia

${ }^{2}$ http://repository.ut.ac.id/ Strategi Pembelajaran Prof. Dr. Sri Anitah W diakses tanggal 15 Oktober 2021
} 


\section{Outcome}

- Meningkatnya layanan yang dapat menjawab kebutuhan sivitas akademika yang lebih baik, efektif dan efisien.

- Tingkat penggunaan layanan bisa meningkat dan mengurangi antrian.

- Meningkatnya kinerja staf di lingkungan Universitas Bengkulu;

- Terlaksananya manajemen talenta yang efektif;

- Meningkatnya budaya kerja pelayanan prima di lingkungan Universitas Bengkulu.

\section{Kajian Pustaka}

\section{a. Pengertian strategi dan Revitalisasi}

Arti strategi berasal dari bahasa Latin strategia, yang diartikan sebagai seni penggunaan rencana untuk mencapai tujuan. Strategi pembelajaran menurut Frelberg \& Driscoll dalam Sri Anitah, ${ }^{2}$ dapat digunakan untuk mencapai berbagai tujuan pemberian materi pelajaran pada berbagai tingkatan, untuk siswa yang berbeda, dalam konteks yang berbeda pula. Istilah Strategi mula-mula dipakai di kalangan militer dan diartikan sebagai seni dalam merancang (operasi) peperangan, terutama yang erat kaitannya dengan gerakan pasukan dan navigasi ke dalam polisi perang yang dipandang paling menguntungkan untuk memperoleh kemenangan. Istilah strategi dewasa ini banyak dipakai oleh bidang-bidang ilmu lainnya, termasuk juga dalam dunia pendidikan. Secara umum strategi mempunyai pengertian sebagai suatu garis besar haluan dalam bertindak untuk mencapai sasaran yang telah ditentukan.

Revitalisasi dalam Kamus Besar Bahasa Indonesia $(2021)^{3}$, berarti proses, cara, dan perbuatan menghidupkan kembali suatu hal yang sebelumnya kurang terberdaya. Revitalisasi adalah proses, cara, perbuatan menghidupkan atau menggiatkan

\footnotetext{
3https://kbbi.web.id/ di akses tanggal 21 oktober 2021

${ }^{4} \mathrm{https} / / /$ repository.its.ac.id/Revitalisasi Perpustakaan ITS diakses tanggal 18 Oktober 202

${ }^{5}$ https://repository.uinjkt.ac.id/ Manajemen dan Peran Perpustakaan Perguruan Tinggi dalam Sistem Kredit Semester (SKS) dan Sumber Belajar. Anwar Syamsudin. Dia akses tanggal 15 Oktober 2021.
}

kembali berbagai kegiatan kesenian tradisional diadakan dalam rangka kebudayaan lama. Revitalisasi fisik merupakan strategi jangka pendek yang dimaksudkan untuk mendorong terjadinya peningkatan kegiatan ekonomi jangka panjang. Kemudian jika dihubungkan dengan kegiatan perpustakaan perguruan tinggi, maka strategi revitalisasi dalam artian khusus bisa diartikan sebagai pola kegiatan yang dilakukan pimpinan dengan pustakawan dalam suatu perwujudan kegiatan pemberian layanan untuk mencapai tujuan yang telah digariskan.

\section{b. Manajemen Pengelolaan perpustakaan}

Manajemen perpustakaan menurut I Ketut Widiasa ${ }^{4}$ pada dasarnya adalah proses mengoptimalkan kontribusi manusia, material, anggaran untuk mencapai tujuan perpustakaan. Dalam pelaksanaannya, perpustakaan perguruan tinggi terkadang masih mengalami hambatan, sehingga dalam pemberian jasa layanan belum bisa berjalan sebagaimana mestinya. Menurut Anwar Syamsudi ${ }^{5}$ manajemen pengelolaan perpustakaan perguruan tinggi merupakan suatu proses kegiatan yang di laksanakan untuk mencapai sasaran dengan cara efektif dan seefisien mungkin dengan memanfaatkan semua sumber daya yaitu sarana, metode dan dana. Agar manajemen berdaya guna maka sasaran maanjemen harus tepat untuk mencapai sasaran.

\section{Metode Penelitian}

Menurut Sugiyono ${ }^{6}$ Penelitian ini dilakukan dengan cara kualitatif yaitu penyajiannya berupa data yang berbentuk kalimat, kata atau gambar. Pendekatan kualitatif adalah penelitian yang menghasilkan penemuan-penemuan yang tidak dapat dicapai dengan menggunakan prosedur statistik atau dengan cara-cara kuantifikasi. Penelitian ini menekankan pada quality atau hal terpenting suatu barang atau jasa. Dalam penelitian ini penulis berusaha menyajikan gambar atau tabel untuk memperjelas suatu informasi. 


\section{Pembahasan Hasil Penelitian}

\section{Tahapan Perubahan Rencana Strategis}

Rencana strategis ${ }^{7}$ (Renstra) merupakan komponen penting dalam manajemen sebuah organisasi karena menjadi panduan dan pedoman dalam memberikan pelayanan kepada stakeholder. Rencana tersebut disusun dan dilaksanakan oleh para manajer puncak dan menengah untuk mencapai tujuan organisasi yang lebih luas. Untuk itu dalam penerapannya di dalam sebuah organisasi, pejabat tertinggi perlu membuat suatu perencanaan strategis yang mana dikoordinasi dengan para pegawai untuk dijalankan bersama demi mencapai tujuan yang diinginkan dari sebuah organisasi. Perencanaan strategis salah satu proses penyusunan jangka panjang yang sangat diperlukan. Perencanaan strategis salah satu proses penyusunan jangka panjang yang sangat diperlukan. Panani ${ }^{8}$ meyatakan bahwa di dalam organisasi modern, perencanaan (planning) merupakan salah satu fungsi manajemen. Disamping fungsii manajemen lainnya, yaitu pengorganisasian (organizing), penyusunan staff (staffing), memimpin (leading) dan pengendalian (controlling). Dalam hal ini, Tujuan dan manfaat untuk organisasi adaptif adalah proyek perubahan yang akan dicapai baik jangka pendek, menengah dan jangka panjang. Tujuan jangka pendek dianggap sebagai pengungkit (leverage) yang dilakukan dalam rangka mencapai tujuan jangka panjang. Fokus pada upaya membangun organisasi adaptif. Manfaat lain proyek perubahan adalah beradaptasi merespon tuntutan perubahan dan tantangan lingkungan strategis. Berikut tahapan rrencana strategisnya;

\section{Jangka Pendek}

Pada tahap ini mencakup pembuatan ke-

${ }^{6}$ https://journal.uinsgd.ac.id/ Konsep Berpikir Sistemik Dalam Penyusunan Rencana Strategis. Fakhrurrazi. Institut. Agama Islam Negeri Langsa. Jurnal Isema. Vol. 6, No. 1, Juni 2021 M/1442 H.

${ }^{7}$ Panani.2021.Merancang Proyek Perubahan. Jakarta:Modul Pelatihan Kepemimpinan Nasional Tingkat II (PKN II). Jakarta: PusdiklatDikbud.

${ }^{8}$ Jaya, Eko. 2016. Analisis Kepuasan Mahasiswa Atas Pelayanan Unit Pelaksana Teknis Perpustakaan Universitas Bengkulu. Bengkulu: Fisip Universitas Bengkulu. bijakan yang menjadi dasar operasional layanan, terbentuknya manajemen pengelola, pembuatan aplikasi, pembuatan panduan dan SOP, Ujicoba serta evaluasi jangka pendek.

2. Jangka Menengah

Pada tahap ini mencakup terbentuknya manajemen pengelola untuk menerapkan pola penyelenggaraan, terlaksananya uji coba layanan bebas pustaka universitas berbasis IT yang dilaksanakan di fakultas, Monev, serta perbaikan aplikasi/pemeliharan

3. Jangka Panjang

Pada tahap ini mencakup terlaksananya peningkatan sistem teknologi informasi sebagai alat untuk mendukung pelaksanaan program yang efektif dan efisien, pengembangan layanan dengan menambah jumlah layanan, implementasi aplikasi serta pemeliharaan

\section{Rencana Strategis Marketing}

Universitas Bengkulu telah menjalankan prinsip pemasaran sektor publik dan terus melakukan peningkatan untuk menjawab kebutuhan masyarakat serta menghadirkan pelayanan yang prima melalui pengembangan layanan terintegrasi di lingkungan Universitas Bengkulu. Strategi marketing yang akan dilakukan dalam proyek perubahan ini menggunakan 2 (dua) pendekatan, yaitu strategi marketing pada proses penyusunan proyek perubahan dan strategi marketing hasil proyek perubahan, kedua pendekatan ini diharapkan dapat mendukung keberhasilan proyek perubahan.

\section{a. Customer (Konsumen)}

Customer/pemustaka perpustakaan merupakan elemen yang paling penting dalam pelayanan ini, dalam sektor publik masyarakat merupakan awal dan akhir dari proses pemberian layanan. UPT Perpustakaan Universitas Bengkulu meli- 
hat sivitas akademika sebagai sumber pertama dalam pemberian layanan. Sebagaimana yang diamanatkan dalam Keputusan Menteri Negara Pendayagunaan Aparatur Negara Nomor 63/ KEP/M.PAN/7/2003 dalam Eko Jaya ${ }^{9}$ adalah segala kegiatan pelayanan yang dilaksanakan oleh penyelenggara pelayanan publik sebagai upaya pemenuhan kebutuhan penerima layanan maupun pelaksanaan, ketentuan peraturan perundang-undangan. UPT Perpustakaan Universitas Bengkulu yang merupakan instansi di bawah kementerian pendidikan sebagai pembina layanan, wajib secara berkesinambungan akan melakukan upaya-upaya untuk melakukan pengembangan layanan terintegrasi guna menjamin tersedianya layanan bebas pustaka di lingkungan Universitas Bengkulu yang sesuai dengan standar yang telah ditetapkan. Sasaran yang dituju dalam layanan ini adalah semua pemustaka atau mahasiswa Universitas Bengkulu tingkat akhir yang akan wisuda.

\section{b. Place (Tempat)}

Place/tempat merupakan elemen rigid dalam manajemen pemasaran, dikarenakan sifatnya yang tetap dan sulit untuk diubah. Lokasi UPT Perpustakaan, ruang baca fakultas serta bagian evaluasi dan pembelajaran mempunyai jarak lokasi yang strategis karena mudah dijangkau oleh mahasiswa. Helen Coote dalam Tine Silvana Rachmawati ${ }^{10}$ menegaskan bahwa place dapat diartikan juga sebagai cara yang digunakan dalam memberikan pelayanan kepada pemustaka, misalnya apakah jam buka layanan menyesuaikan dengan kebutuhan para pemustaka, apakah pemustaka dapat dengan mudah memanfaatlatkan layanan tersebut, apakah fitur-fitur layanan telah sesuai dengan kebutuhan serta dapat den-

9http://jurnalbaca pdiilipi.go id/ Faktor 4p, 3p Dan 4c Serta Aplikasinya Dalam Kegiatan Pemasaran Perpustakaan (Library Marketing) Tine Silvana Rachmawati diakses tanggal 18 Oktober 2021.

${ }^{10} \mathrm{http} / / /$ jurnalbaca.pdii.lipi.go.id/ Faktor 4p, 3p Dan 4c Serta Aplikasinya Dalam Kegiatan Pemasaran Perpustakaan (Library Marketing) Tine Silvana Rachmawati diakses tanggal 18 Oktober 2021. gan mudah difahami oleh pemustaka, apakah ada staf profesional yang ditempatkan dibagian layanan tersebut, bagaimana penanganan apabila terjadi kendala, serta berapa lama waktu yang dibutuhkan untuk melakukan proses transaksi khususnya bebas pustaka online.

\section{c. Product}

Produk atau jasa yang ditawarkan oleh perpustakaan yang pada dasarnya berupa informasi baik terekam maupun tercetak. Pengertian produk bersifat intangible (tidak terlihat). Mengenai produk informasi ini, David Aaker dalam Tine Silvana Rachmawati ${ }^{11}$ mendeskripsikan konsep produk informasi menjadi empat tingkatan, yakni sebaga berikut (I) Generic product. (2) Expected product/produk yang diharapkan (dikerjakan atau dikurangi), (3) Augmented product/produk tambahan (disesuaikan dengan pemustaka), (4) Potential product. Produk tersembunyi, seperti penyajian informasi yang baru dan inovatif. Produk apa untuk menyelesaikan akar masalah yang ada di Universitas Bengkulu? Produk ini berupa aplikasi layanan bebas pustaka yang dikeluarkan oleh Universitas Bengkulu bekerjasama Bank Negara Indonesia (BNI), yang memberikan surat bebas pustaka untuk mahasiswa yang telah lulus, serta menyerahkan hasil laporan akhir studi kepada universitas.

\section{d. Price (Harga)}

SDM Non Pendidik yang ada di lingkungan Kemendikbudristek yang mendapat kesempatan mengikuti pengembangan kompetensi SDM memperoleh ilmu pengetahuan dan pengalaman yang akan meningkatkan kompetensinya sehingga akan berdampak kepada pengembangan karirnya.

\section{e. Promotion}

Tujuan utama promosi Menurut Mc.Carthy dalam Tine Silvana Rachmawati ${ }^{12}$ adalah (I) memberitahu, (2) membujuk, (3) mengingat- 
kan. Sedangkan tugas utama promosi dikenal dengan model AIDA (attention, interest, desire dan action). Peranan promosi dalam kegiatan pemasaran perpustakaan merupakan bagian yang sangat penting dalam mengkomunikasikan pesan-pesan pada individu, kelompok atau organisasi baik langsung maupun tidak langsung tentang suatu produk informasi yang dihasilkan oleh lembaga perpustakaan. Elemen price/harga merupakan elemen yang disadari sangat sensitif keberadaannya, universitas dan pemerintah tidak boleh mengambil untung dari mahasiswa namun universitas dan pemerintah harus memberikan untung kepada pihak mahasiswa berupa keefektifan dan keefisienan layanan dalam sistem ini. Akuntabilitas dapat dipertanggungjawabkan karena semua pembayaran bebas pustaka akan masuk dalam akun bank universitas langsung. Promotion merupakan elemen akhir yang mendukung pelaksanaan program bebas pustaka terintegrasi.

\section{Tim Efektif}

Dalam proyek perubahan ini mencoba menyajikan organisasi proyek perubahan yang agile, dimana terdiri dari mentor, coach, project leader, tim efektif (tim teknis dan tim administrasi) dimana masing-masing memiliki tugas pokok dan fungsi yang berbeda.

Gambar 2: Organisasi Proyek Perubahan

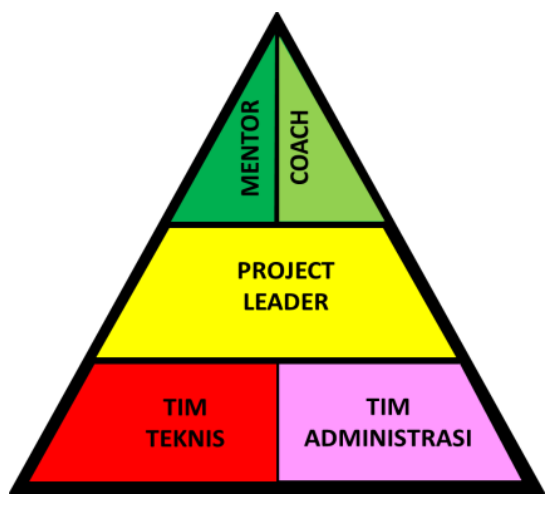

${ }^{11}$ http://jurnalbaca.pdii.lipi.go.id/ Faktor 4p, 3p Dan 4c Serta Aplikasinya Dalam Kegiatan Pemasaran Perpustakaan (Library Marketing) Tine Silvana Rachmawati diakses tanggal 18 Oktober 2021.

\section{Tahapan Perubahan Strategis}

\section{a. Identifikasi pemangku kepentingan}

Stakeholder adalah pihak-pihak yang terkait dengan proyek perubahan, yang memiliki pengaruh terhadap hasil proyek perubahan ini. Stakeholder terdiri dari dari internal dan eksternal. Stakeholder internal adalah yang berada dalam internal proyek perubahan seperti Rektor, para Wakil Rektor, Biro Sumber Daya, Bidang Evaluasi dan Pengajaran, UPT Perpustakaan, serta ruang baca fakultas. Sedangkan stakeholder eksternal yang berada di luar unit kerja seperti Dekan Fakultas, Wakil Dekan Bidang Akademik, LPTIK, BNI serta mahasiswa. Pengaruh dari para stakeholder terhadap keberhasilan proyek perubahan ini dapat dijbarkan dalam pengaruh; kuat, sedang, atau lemah, dan dapat bersifat positif berarti mendukung berarti mendukung atau negatif berarti tidak mendukung atau menghambat.

Tabel 1. Manfaat Proyek Perubahan

\begin{tabular}{|c|c|c|c|c|c|}
\hline \multirow[t]{2}{*}{ No } & \multirow[t]{2}{*}{$\begin{array}{c}\text { Pemangku } \\
\text { Kepentingan }\end{array}$} & \multicolumn{2}{|c|}{$\begin{array}{c}\text { Tingkat } \\
\text { Kepentingan }\end{array}$} & \multicolumn{2}{|c|}{ Pengaruh } \\
\hline & & Tinggi & Rendah & Kuat & Lemah \\
\hline & Internal & & & & \\
\hline 1 & Rektor & $\sqrt{ }$ & & $\sqrt{ }$ & \\
\hline 2 & $\begin{array}{l}\text { Wakil Rektor } \\
\text { Bidang } \\
\text { Akademik }\end{array}$ & $\sqrt{ }$ & & $\sqrt{ }$ & \\
\hline 3 & $\begin{array}{l}\text { Wakil Rektor } \\
\text { Bidang Sumber } \\
\text { Daya }\end{array}$ & $\sqrt{ }$ & & $\sqrt{ }$ & \\
\hline 4 & $\begin{array}{l}\text { Wakil Rektor } \\
\text { Bidang } \\
\text { Kemahasiswaan }\end{array}$ & $\sqrt{ }$ & & $\sqrt{ }$ & \\
\hline 5 & $\begin{array}{l}\text { Wakil Rektor } \\
\text { Bidang } \\
\text { Perencanaan } \\
\text { dan Kerjasama }\end{array}$ & $\sqrt{ }$ & & $\sqrt{ }$ & \\
\hline 6 & $\begin{array}{l}\text { Kepala Biro } \\
\text { Sumber Daya }\end{array}$ & $\sqrt{ }$ & & $\sqrt{ }$ & \\
\hline 7 & $\begin{array}{l}\text { Kepala Biro } \\
\text { PPK }\end{array}$ & $\sqrt{ }$ & & & \\
\hline 8 & $\begin{array}{l}\text { Bidang Evaluasi } \\
\text { dan } \\
\text { Pembelajaran }\end{array}$ & $\sqrt{ }$ & & $\sqrt{ }$ & \\
\hline 9 & $\begin{array}{l}\text { UPT } \\
\text { Perpustakaan }\end{array}$ & $\sqrt{ }$ & & $\sqrt{ }$ & \\
\hline 10 & $\begin{array}{l}\text { Ruang Baca } \\
\text { Fakultas }\end{array}$ & $\sqrt{ }$ & & $\sqrt{ }$ & \\
\hline & Eksternal & & & & \\
\hline 11 & $\begin{array}{l}\text { Dekan dan } \\
\text { Wakil Dekan } \\
\text { Bidang } \\
\text { Akademik } \\
\text { Fakultas }\end{array}$ & & $\sqrt{ }$ & $\sqrt{ }$ & \\
\hline 11 & LPTIK & & $\sqrt{ }$ & $\sqrt{ }$ & \\
\hline 12 & $\begin{array}{l}\text { Bank Negara } \\
\text { Indonesia }\end{array}$ & & $\sqrt{ }$ & $\sqrt{ }$ & \\
\hline 13 & Mahasiswa & & $\sqrt{ }$ & $\sqrt{ }$ & \\
\hline
\end{tabular}


Berdasarkan analisis pemetaan kepentingan dan pengaruh setiap stakeholder terhadap proyek perubahan yang akan dilaksanakan menunjukkan bahwa stakeholder internal perannya dan pengaruhnya dalam proyek perubahan ini memiliki tingkat kepentingan tinggi dan berpengaruh kuat dalam pengambilan kebijkan. Sedangkan stakeholder eksternal memiliki tingkat kepentingan yang rendah dan pengaruh yang kuat. Hal ini dipandang bahwa proyek perubahan ini hanya sebagai pengambil manfaat atas keberhasilan proyek perubahan tersebut.

Gambar 3. Peta Stakeholders

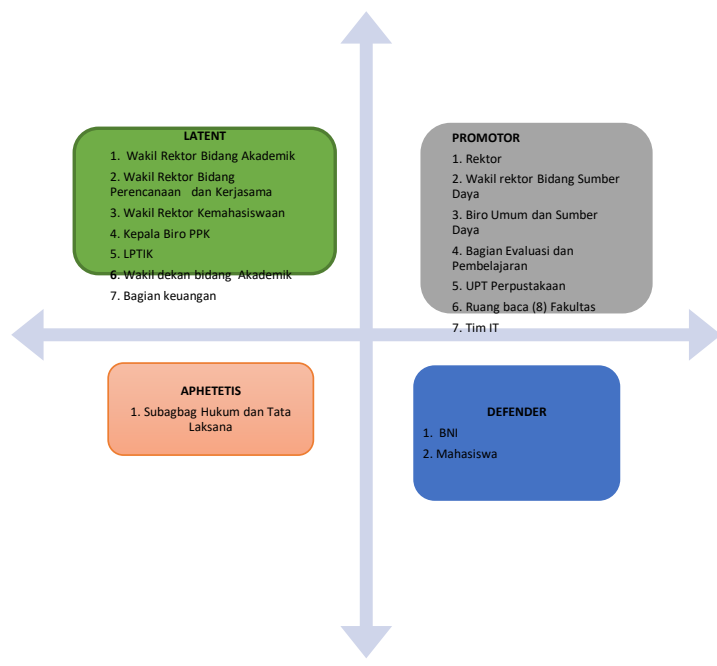

\section{a. Peta Stakeholder}

Pemetaan stakeholder diperoleh melalui proses identifikasi para stakeholder yang terlibat dan terkena dampak dari proyek perubahan baik secara langsung maupun tidak langsung. Kemudian diidentifikasi lagi sifat dukungan dari masingmasing stakeholder positif $(+)$, negatif $(-)$, atau netral (+/-). Stakeholder yang memiliki dukungan positif berarti mendukung karena menerima dampak positif dari proyek dan diprediksi akan mendukung karena menerima dampak positif dari proyek perubahan. Selanjutnya stakeholder juga akan diidentifikasi terkait tinggi rendahnya kepentingan dan tinggi rendahnya pengaruh terhadap proyek perubahan. Setelah dilakukan identifikasi dan dikelompokkan menjadi empat kuadran seperti gambar di dibawah ini;

\section{Gambar 4. Pemetaan Stakeholder} berdasarkan peran

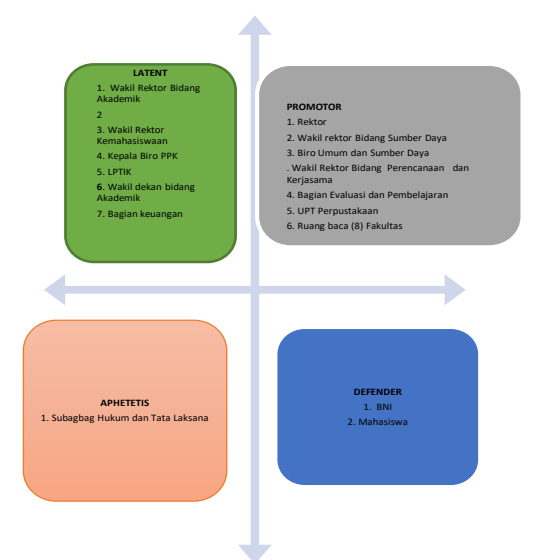

Pada proyek perubahan ini stakeholder dipetakan berdasarkan peran dan pengaruh serta pemetaan stakeholder berdasarkan tanggapan/ respon stakeholder. Kedua pemetaan tersebut secara raingkas dapat dijelaskan sebagai berikut;

Tabel 2. Peran dan Pengaruh Stakeholder

\begin{tabular}{|c|c|c|c|c|c|c|c|c|}
\hline $\begin{array}{l}\mathrm{N} \\
\mathrm{O}\end{array}$ & $\begin{array}{c}\text { Pemang } \\
\text { ku } \\
\text { Kepenti } \\
\text { ngan }\end{array}$ & $\begin{array}{l}\text { Tingk } \\
\text { at } \\
\text { Kepen } \\
\text { tingan }\end{array}$ & & & $\begin{array}{l}\text { Peng } \\
\text { aruh }\end{array}$ & & & $\begin{array}{l}\text { Uraian } \\
\text { Keterl } \\
\text { ibatan }\end{array}$ \\
\hline & & Tinggi & $\begin{array}{l}\text { Sed } \\
\text { ang }\end{array}$ & $\begin{array}{l}\text { Ren } \\
\text { dah }\end{array}$ & Kuat & $\begin{array}{l}\text { Sed } \\
\text { ang }\end{array}$ & $\begin{array}{c}\mathrm{Le} \\
\mathrm{ma} \\
\mathrm{h}\end{array}$ & \\
\hline A & $\begin{array}{l}\text { INTER } \\
\text { NAL }\end{array}$ & & & & & & & \\
\hline 1 & Rektor & $\sqrt{ }$ & & & $\sqrt{ }$ & & & \\
\hline 2 & $\begin{array}{l}\text { Wakil } \\
\text { Rektor } \\
\text { Bidang } \\
\text { Akadem } \\
\text { ik }\end{array}$ & $\sqrt{ }$ & & & $\sqrt{ }$ & & & \\
\hline 3 & $\begin{array}{l}\text { Wakil } \\
\text { Rektor } \\
\text { Bidang } \\
\text { Sumber } \\
\text { Daya }\end{array}$ & $\sqrt{ }$ & & & $\sqrt{ }$ & & & \\
\hline 4 & $\begin{array}{l}\text { Wakil } \\
\text { Rektor } \\
\text { Bidang } \\
\text { Kemaha } \\
\text { siswaan }\end{array}$ & $\sqrt{ }$ & & & $\sqrt{ }$ & & & \\
\hline 5 & $\begin{array}{l}\text { Wakil } \\
\text { Rektor } \\
\text { Bidang } \\
\text { Perenca } \\
\text { naan dan } \\
\text { Kerjasa } \\
\text { ma } \\
\end{array}$ & $\sqrt{ }$ & & & $\sqrt{ }$ & & & \\
\hline 6 & $\begin{array}{l}\text { Kepala } \\
\text { Biro } \\
\text { PPK } \\
\end{array}$ & $\sqrt{ }$ & & & $\sqrt{ }$ & & & \\
\hline 7 & $\begin{array}{l}\text { Kepala } \\
\text { Biro } \\
\text { Sumber } \\
\text { Daya }\end{array}$ & $\sqrt{ }$ & & & $\sqrt{ }$ & & & \\
\hline 8 & $\begin{array}{l}\text { Kepala } \\
\text { Bagian }\end{array}$ & $\sqrt{ }$ & & & $\sqrt{ }$ & & & \\
\hline
\end{tabular}




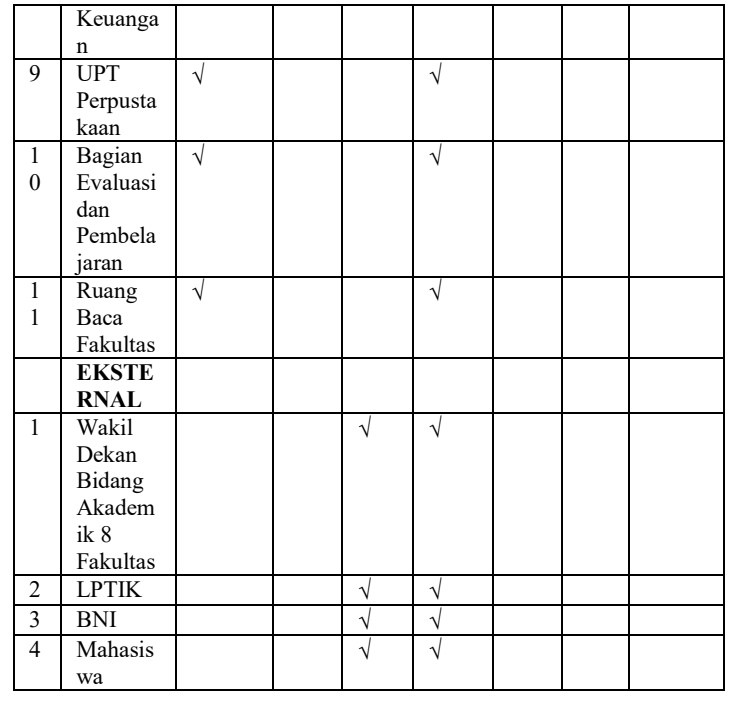

Berdasarkan hasil analisis pemetaan kepentingan dan pengaruh setiap stakeholder terhadap proyek perubahan yang akan dilaksanakan, menunjukkan bahwa stakeholder internal perannya dan pengaruhnya dalam proyek perubahan memiliki tingkat kepentingan tinggi dan berpengaruh kuat dalam pengambilan kebijakan. Sedangakn stakeholder ksternal memiliki tingkat kepentingan rendah dan pengaruh kuat dalam hal ini dipandang bahwa proyek perubahan ini hanya sebagai pengambil manfaat atas keberhasilan proyek perubahan tersebut.

Gambar 5. Peta Stakeholders berdasarkan peran dan pengaruh

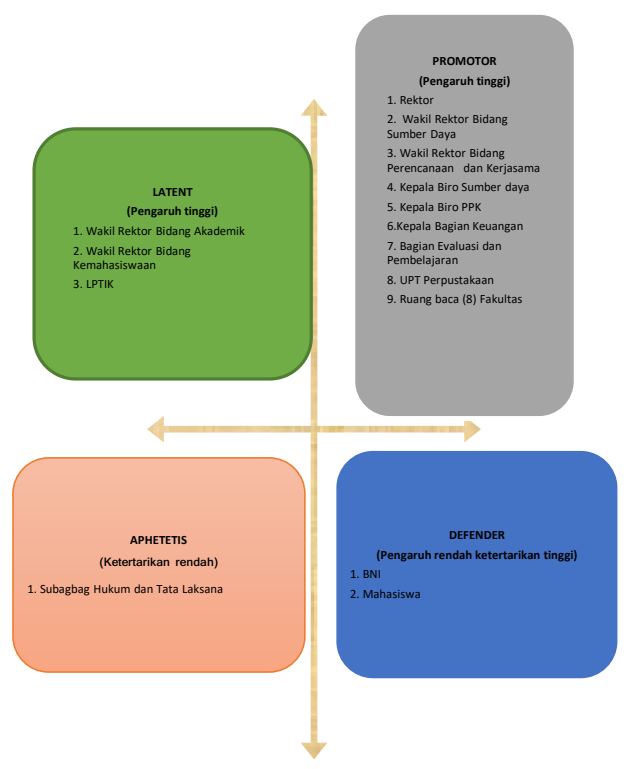

Setelah dilakukan identifikasi para stakeholder, maka selanjutnya dilakukan tahapan penentuan peringkat dan strategi kerjasama dengan para stakeholder tersebut. adapun kategori peringkat dan strategi kerjasama dengan stakeholder berdasarkan pengaruh, minat, kepentingan terhadap proyek perubahan dapat diklasifikasikan sebagai berikut;

\section{Latens:}

pada kuadran ini diidentifikasi Pemangku kepentingan yang kurang memiliki kepentingan terhadap proyek perubahan, tetapi memiliki pengaruh yang besar terhadap proyek perubahan maupun pemangku kepentingan lainnya adalah Wakil Rektor Bidang Akademik, Wakil Rektor Bidang Kemahasiswaan, LPTIK Universitas Bengkulu memiliki kepentingan rendah, tetapi berengaruh tinggi dalam keterlibatan tahapan kegiatan proyek perubahan.

\section{Promoters:}

Promoter adalah pemangku kepentingan yang memiliki kepentingan tinggi dan pengaruh tinggi/ besar terhadap proyek perubahan. Pemangku kepentingan yang masuk dalam kuadran ini adalah: Rektor, Wakil Rektor Bidang Sumber Daya, Kepala Biro Sumber daya, Wakil rektor Bdang Perencanaan dan Kerja Sama, Biro Umum dan Sumber Daya, Biro PPK, Bagian Keuangan, Bagian Evaluasi dan Pembelajaran, UPT Perpustakaan, Ruang baca (8) Fakultas memiliki pengaruh dan kepentingan yang tinggi terhadap terlaksananya proyek perubahan yang dilaksanakan.

\section{Defenders:}

Pemangku kepentingan yang tergolong memiliki kepentingan tinggi, tetapi pengaruh rendah. Pemangku kepentingan yang masuk dalam kuadran ini adalah Bank Negara Indonesia dan mahasiswa Universitas Bengkulu memiliki kepentingan tinggi dalam akses ketersediaan data tetapi kurang memiliki pengaruh dan jalannya proyek perubahan. 


\section{Apathetics:}

pada kuadran ini adalah pemangku kepentingan yang kurang memiliki pengaruh dan kurang juga memiliki kepentingan. Pemangku kepentingan pada kuadran ini adalah Subagbag Hukum dan Tata Laksana tidak mempunyai kepentingan khusus terhadap jalannya proyek perubahan.

Strateginya adalah:

Dengan memperhatikan kelompok stakeholder tersebut di atas, strategi yang dilakukan untuk mempengeruhinya antara lain:

1) Terhadap kelompok Latens, strategi yang dilakukan dengan memberikan informasi mengenai maksud, tujuan, manfaat, output yang dihasilkan dari pelaksanaan proyek perubahan. Dengan penyampaian hal tersebut mereka menjadi tertarik untuk mendukung pelaksanaan proyek perubahan, karena pada dasarnya mereka juga ada kepentingan khusus dalam usulan perencanaan.

2) Terhadap kelompok Promoters, dengan cara memberikan informasi untuk meyakinkan bahwa tahapan ini yang akan dilaksanakan pada proyek perubahan sangat diperlukan dan sangat berguna. Hal-hal yang dikomunikasin antara lain dengan menjelaskan maksud dan tujuan, manfaat, output yang dihasilkan serta impact dari proyek perubahan serta menyampaikan dukugan-dukungan yang diperlukan untuk suksesnya pelaksanaan. Dari komunikasi yang dibangn menghasilkan dukungan secara penuh dan memberi perhatian khusus kepada pelaksanaan tahapan proyek perubahan ini.

3) Terhadap kelompok Defenders, yang dilakukan dengan memberikan motivasi untuk menyakini bahwa tahapan pelaksanaan proyek perubahan ini berkaitan dengan tugas pokok yang ada dimasing-masing unit yang harus dilaksanakan dan merupakan kesempatan untuk menunjukkan bahwa kita dalam mendukung misi Universitas Bengkulu yaitu Word Class University pada tahun 2025.
4) Terhadap kelompok Apathetics, yang dilakukan adalah memberikan informasi agar mereka memberikan perhatian terhadap tahapan proyek perubahan ini walaupun kelompok ini tidak memiliki kepentingan maupun kekuatan, dan dalam kenyataannya kelompok ini tidak menjadi penghambat dari proyek perubahan yang dilakukan.

\section{d. Tahapan Perubahan Strategis.}

Agar proyek perubahan ini dapat dilaksanakan tepat waktu dan tepat sasaran, maka proyek perubahan ini dilakukan melalui tahapan-tahapan tahapan jangka pendek, tahapan jangka menengah serta jangka panjang

\section{1) Tahapan Persiapan Rancangan Proyek Perubahan}

Tahapan ini merupakan kegiatan penyiapan Rancangan Proyek Perubahan meliputi konsultasi dengan Mentor dan Coach, Pembentukan Tim Efektif, FGD Tim Efektif, FGD dengan Pemangku kepentingan, Penyusunan RPP dan Seminar RPP dengan rincian kegiatan sebagai berikut: Milestone jangka pendek, jangka menengah, dan jangka Panjang dapat digambarkan sebagai berikut:

Tabel 3: Milestone Strategi Revitalisasi Manajemen Pengelolaan Perpustakaan di Universitas Bengkulu

\begin{tabular}{|c|c|c|c|c|c|c|c|c|c|c|c|c|}
\hline \multicolumn{2}{|c|}{ Minggu } & 1 & 2 & 3 & 4 & 5 & 6 & 7 & 8 & 9 & $\begin{array}{l}1 \\
0\end{array}$ & $\begin{array}{l}\mathrm{Pj} \\
\mathrm{b}\end{array}$ \\
\hline \multicolumn{2}{|c|}{$\begin{array}{l}\text { Tersusunnya } \\
\text { Kebijakan yang } \\
\text { Menjadi Dasar } \\
\text { Operasional } \\
\text { Layanan }\end{array}$} & & & & & & & & & & & \\
\hline \multicolumn{2}{|c|}{$\begin{array}{l}\text { a. FGD (Forum } \\
\text { grup Discussion) } \\
\text { Dengan } \\
\text { Stakeholder } \\
\text { Terhadap } \\
\text { Kebutuhan } \\
\text { Peraturan } \\
\end{array}$} & & & & & & & & & & & \\
\hline a. & $\begin{array}{l}\text { Pemben } \\
\text { tukan } \\
\text { Tim } \\
\text { Efektif }\end{array}$ & & & & & & & & & & & \\
\hline b. & $\begin{array}{l}\text { Penyusu } \\
\text { nan } \\
\text { peratur } \\
\text { an atau } \\
\text { kebijaka } \\
\text { n }\end{array}$ & & & & & & & & & & & \\
\hline
\end{tabular}




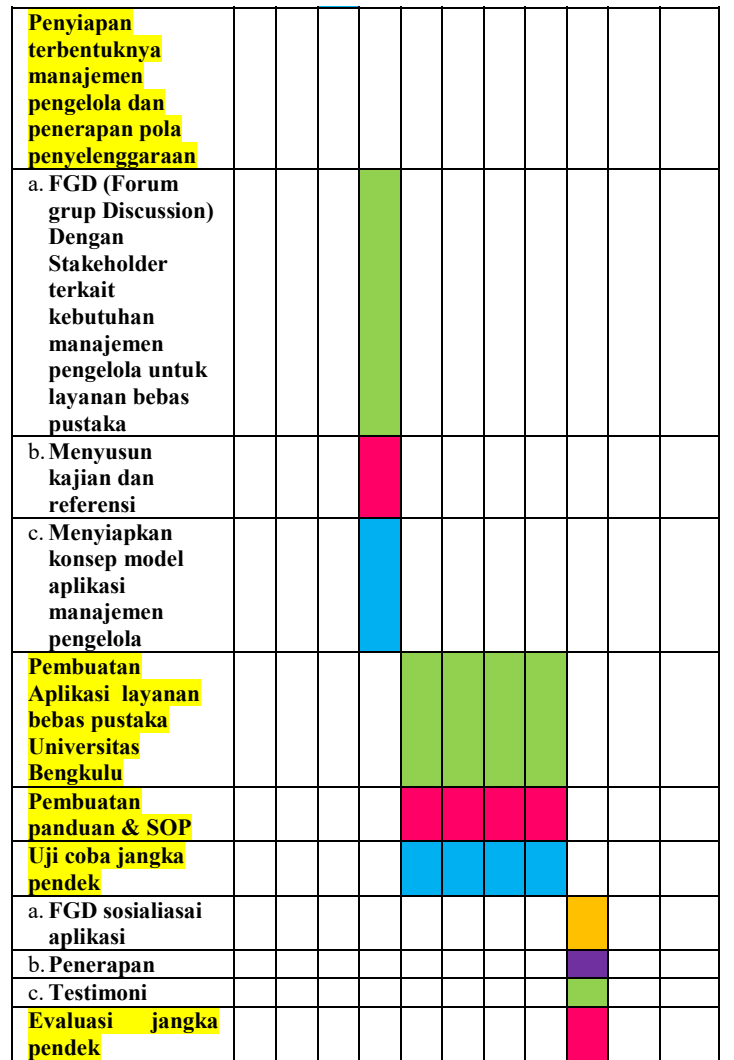

\section{Pelaksanaan Proyek Perubahan}

\section{Capaian Tahapan Rencana Strategis}

Dalam melaksanakan dan merealisasikan tujuan yang ingin dicapai dalam proyek perubahan tersebut, kami membagi kegiatan tersebut dalam 3 tahapan, yaitu jangka pendek yang dilaksanakan dalam waktu 2 bulan, jangka menengah yang dilaksanakan dalam jangka waktu 4 bulan dan jangka panjang yang dilaksanakan lebih dari 4 sd 5 tahun. Adapun tujuan pelaksanaan proyek perubahan di Universitas Bengkulu di rumuskan dalam tahapan berikut :

A. Tahapan Jangka Pendek:

a) Tersusunnya Kebijakan yang Menjadi Dasar Operasional Layanan

- FGD (Forum grup Discussion) Dengan Stakeholder Terhadap Kebutuhan Peraturan

- Pembentukan Tim Efektif

- Penyusunan peraturan atau kebijakan

b) Penyiapan terbentuknya manajemen pengelola dan penerapan pola penyelenggaraan
- FGD Dengan Stakeholder terkait kebutuhan manajemen pengelola untuk layanan bebas pustaka

- Menyusun kajian dan referensi

- Menyiapkan konsep model aplikasi manajemen pengelola

c) Pembuatan Aplikasi layanan bebas pustaka Universitas Bengkulu

- Uji coba jangka pendek

- FGD sosialiasai aplikasi

- Penerapan

- Testimoni

\section{d) Evaluasi jangka pendek}

\section{B.Tahapan Jangka Menengah:}

a) Terbentuknya manajemen pengelola untuk menerapkan pola penyelenggaraan

- Rapat pembahasan tupoksi

- Rapat pembahasan standar operasi

- Penetapan manajemen pengelola

b) Terlaksananya uji coba layanan bebas pustaka Universitas berbasis IT yang dilaksanakan di fakultas

- Persiapan infrastruktur server IT

- Persiapan kebutuhan hardware IT

- Pengembangan software sistem operasional

- Pengembangan software sistem pengelolaan keuangan

- Pengembangan software sistem SDM

- Pelatihan penggunaan sistem

c) Monitoring dan Evaluasi

d) Perbaikan aplikasi/pemeliharan

C. Tahapan Jangka Panjang:

a) Terlaksananya peningkatan sistem teknologi informasi sebagai alat untuk mendukung pelaksanaan program yang efektif dan efisien

- Rapat evaluasi

- Rapat kebutuhan peningkatan sistem

- Peningkatan sistem

b) Pengembangan layanan dengan menam- 
bah jumlah layanan

- Sosialisasi

- Koordinasi

- Lounching secara bertahap

- Operasional

c) Implementasi aplikasi

d) Pemeliharaan

\section{Implementasi Solusi Terhadap Kendala}

Selama pelaksanaan Proyek Perubahan terdapat beberapa kendala yang terjadi, namun kendala tersebut dapat diatasi menggunakan strategi sebagaimana dalam tabel berikut:

Tabel 4: Kendala dan Strategi Mengatas Kendala

\begin{tabular}{|c|c|c|c|}
\hline No & $\begin{array}{l}\text { Potensi } \\
\text { kendala } \\
\text { yg } \\
\text { mungkin } \\
\text { terjadi }\end{array}$ & $\begin{array}{l}\text { Resiko } \\
\text { yg } \\
\text { akan } \\
\text { terjadi }\end{array}$ & $\begin{array}{l}\text { Strategi } \\
\text { mengatasinya }\end{array}$ \\
\hline 1 & \begin{tabular}{l|l} 
Staf akan & \\
merasa & \\
terganggu \\
karena \\
merasa di \\
zona \\
nyaman
\end{tabular} & $\begin{array}{l}\text { Staff } \\
\text { enggan } \\
\text { untuk } \\
\text { belajar } \\
\text { hal-hal } \\
\text { baru }\end{array}$ & $\begin{array}{l}\text { Manajemen } \\
\text { pengelola } \\
\text { secara terus } \\
\text { menerus } \\
\text { mengedukasi } \\
\text { operator } \\
\text { terdampak } \\
\text { agar bisa } \\
\text { membuat } \\
\text { suasana } \\
\text { layanan bebas } \\
\text { pustaka bisa } \\
\text { berjalan } \\
\text { dengan baik }\end{array}$ \\
\hline T & 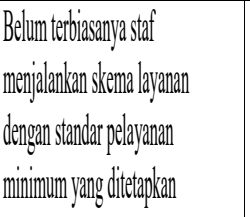 & $\begin{array}{l}\text { Kineriakurang } \\
\text { maksimal }\end{array}$ & 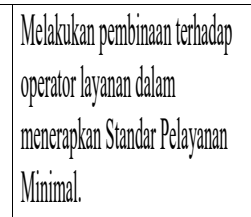 \\
\hline 3 & $\begin{array}{l}\text { Belum tersedianya angogaran yang } \\
\text { dibutuhkann }\end{array}$ & 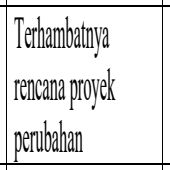 & $\begin{array}{l}\text { Mengajulkan revisis angegaran pada } \\
\text { Biro Unum dan Sumber Daya }\end{array}$ \\
\hline 4 & $\begin{array}{l}\text { Terbatassyya wadtu pelaksanaan } \\
\text { kegriatan }\end{array}$ & $\begin{array}{l}\text { Provel pertuahanan } \\
\text { meniadid terhambat }\end{array}$ & $\begin{array}{l}\text { Melakukan Komunikasi setta } \\
\text { komitmen untuk bekerijasama }\end{array}$ \\
\hline
\end{tabular}

\section{Kesimpulan dan Saran \\ Kesimpulan}

1. Tim efektif yang terbentuk berdasarkan Surat Keputusan (SK) Sekretaris Jenderal Kemendikbud No. 1550/ UN30/hk/2021 Tahun 2021 tanggal 10 Mei 2021 telah berhasil membangun dan mendorong perubahan dalam strategi revitalisasi manajemen pengelolaan perpustakaan di Universitas Bengkulu;

2. Terlaksananya koordinasi dan kolaborasi yang efektif dengan pemangku kepentingan internal (Biro USD, Bagian Evaluasi dan Pembelajaran, UPT Perpustakaan, Ruang baca fakultas), maupun eksternal (LPTIK, Wakil Dekan Bidang Akademik 8 fakultas) telah berhasil menghasilkan empat produk kunci dari Proyek perubahan ini .

3. Melalui Proyek Perubahan ini sudah ada dasar hukum layanan bebas pustaka sebagai bahan awal dalam Pengembangan layanan prima di Universitas Bengkulu.

4. Layanan bebas pustaka melalui melalui aplikasi Bebaspustaka.unib.ac.id telah mengintegrasikan sistem pengelolaan perpustakaan yang berkaitan dengan bebas pustaka universitas.

\section{Saran}

Dengan adanya proyek perubahan ini, beberapa rekomendasi yang dapat disampaikan untuk menyelesaikan milestone jangka menengah dan jangka panjang, diantaranya adalah sebagai berikut:

a. Kepala lembaga selalu memonitor pelaksanaan dan perkembangan kegiatan yang telah dijadwalkan dalam milestone jangka menengah dan panjang, agar target dari program proyek perubahan dapat tercapai;

b. Fungsi teknologi dan informasi di Universitas Bengkulu sebaiknya mengikuti perkembangan pola layanan sejalan dengan perkembangan teknologi, yang cepat, tepat, aman dan transparan, yang pada ending-nya mencip- 
takan layanan yang mempunyai sense Good Governance.

\section{Daftar Pustaka}

Anitah W, Sri (2021) Strategi Pembelajaran http:// repository.ut.ac.id/ diakses tanggal 15 Oktober 2021

Fakhrurrazi (2021) Konsep Berpikir Sistemik Dalam Penyusunan Rencana Strategis. https:// journal.uinsgd.ac.id/ diakses tenggal 18 Oktober 2021.

Jaya, Eko. 2016. Analisis Kepuasan Mahasiswa Atas Pelayanan Unit Pelaksana Teknis Perpustakaan Universitas Bengkulu. Bengkulu: Fisip Universitas Bengkulu
Panani (2021) Merancang Proyek Perubahan. Modul Pelatihan Kepemimpinan Nasional Tingkat II (PKN II). Jakarta: PusdiklatDikbud.

Rachmawati, Tine Silvana (2021) http://jurnalbaca.pdii.lipi.go.id/ diakses tanggal 18 Oktober 2021.

Syamsudin, Anwar (2021) Manajemen dan Peran Perpustakaan Perguruan Tinggi dalam Sistem Kredit Semester (SKS) dan Sumber Belajar. . https://repository.uinjkt.ac.id/ dia akses tanggal 15 Oktober 2021.

Widyo Andoko, Bhimo (2020) Strategi Peningkatan Kinerja Layanan Lembaga Pendidikan Tinggi Wilayah V Yogyakarta yang Terintegrasi dan Akuntabel. Jakarta: PusdiklatDikbud. 